\title{
An Imbalance between Frequency of CD4+CD25+FOXP3+ Regulatory T Cells and CCR4+ and CCR9+ Circulating Helper T Cells Is Associated with Active Perennial Allergic Conjunctivitis
}

\author{
J. Galicia-Carreón, ${ }^{1}$ C. Santacruz, ${ }^{2}$ J. Ayala-Balboa, ${ }^{2}$ A. Robles-Contreras, ${ }^{2}$ \\ S. M. Perez-Tapia, ${ }^{3}$ Y. Garfias, ${ }^{4}$ E. Hong, ${ }^{1}$ and M. C. Jiménez-Martínez ${ }^{2,4}$ \\ ${ }^{1}$ Department of Pharmacobiology, CINVESTAV, IPN, P.O. Box 22106, 14330 Mexico, DF, Mexico \\ ${ }^{2}$ Department of Immunology and Research Unit, Institute of Ophthalmology "Conde de Valenciana Foundation", \\ 06800 Mexico, DF, Mexico \\ ${ }^{3}$ Unit of R\&D in Bioprocesses (UDIBI), Department of Immunology, National School of Biological Sciences, \\ National Polytechnic Institute, 11340 Mexico, DF, Mexico \\ ${ }^{4}$ Immunology Lab, Department of Biochemistry, Faculty of Medicine, National Autonomous University of Mexico, \\ P.O. Box 70159, 04510 Mexico, DF, Mexico
}

Correspondence should be addressed to M. C. Jiménez-Martínez; mcjimenezm@institutodeoftalmologia.org

Received 27 July 2013; Revised 15 October 2013; Accepted 22 October 2013

Academic Editor: Oscar Bottasso

Copyright (C) 2013 J. Galicia-Carreón et al. This is an open access article distributed under the Creative Commons Attribution License, which permits unrestricted use, distribution, and reproduction in any medium, provided the original work is properly cited.

\begin{abstract}
Allergic conjunctivitis (AC) is one of the most common eye disorders in ophthalmology. In mice models, it has been suggested that control of allergic conjunctivitis is a delicate balance between Tregs and inflammatory migrating effector cells. Our aim was to evaluate the frequency of Tregs and the frequency of homing receptors expressing cells in peripheral blood mononuclear cells (PBMC) from patients with perennial allergic conjunctivitis (PAC). The analyses of phenotypic markers on CD4+ T cells and both soluble or intracellular cytokines were performed by flow cytometry. CD4+CD25+ cells were 15 times more frequent in PBMC from patients than HC; the vast majority of these CD4+CD25+ cells were FOXP3-, and most of CD4+ T cells were CCR4+ and CCR9+ cells. Upon allergen-stimulation, no significant changes were observed in frequency of Treg; however, an increased frequency of CD4+CCR4+CCR9+ cells, CD4+CD103+ cells and CD4+CD108+ cells with increased IL-5, IL-6, and IL-8 production was observed. These findings suggest an immune dysregulation in PAC, characterized by diminished frequency of Tregs and increased frequency of circulating activated CD4+ T cells; upon allergen-stimulation, these cells were expressing cell-surface molecules related to mucosa homing and were able to trigger an inflammatory microenvironment.
\end{abstract}

\section{Introduction}

Allergies represent the most frequent chronic diseases worldwide [1]; ocular allergy is one of the most common ocular conditions encountered in clinical practice. Allergic conjunctivitis (AC) includes a spectrum of a number of traditional overlapping conditions that range from intermittent to persistent signs and symptoms, and these are fluctuating in severity and presentation. AC could be as mild forms with transient inflammation, such as seasonal (SAC) and perennial allergic conjunctivitis (PAC), or as more severe persistent and chronic inflammatory forms such as vernal keratoconjunctivitis (VKC) and atopic keratoconjunctivitis (AKC) [2, 3]. Allergic conjunctivitis is initiated by the predominant activation of $\mathrm{CD} 4+\mathrm{T}$ cells to environmental allergens, culminating in a $T h 2$ response with generation of IgE antibodies [4]. The CD4+ T cells from allergic patients are resistant to apoptosis and produce large amounts of IL-5 [5], favouring chronicity and perpetuating inflammation and relapsing-remitting symptoms. It is well known that in the chronic forms of allergic conjunctivitis $\mathrm{CD} 4+\mathrm{T}$ cells are able to migrate to the ocular mucosa, maintaining the inflammatory process [6]. In 
mice models of ocular allergy, it has been demonstrated that CD4+CD25+FOXP3+ regulatory $\mathrm{T}$ cells (Tregs) influence the expression of immune-mediated allergic inflammation in conjunctiva, [7] counteracting inflammation through antiinflammatory cytokines such as TGF- $\beta$ and IL-10 $[7,8]$. Therefore, it appears that control of allergic conjunctivitis is a delicate balance between Tregs and inflammatory migrating effector cells. In humans, intraepithelial leukocytes in the ocular surface express human mucosal lymphocyte antigen (HML or CD103) in nonpathological conditions [9], whereas in chronic allergic status, infiltrating CD4+ T cells are CCR3+ and/or CXCR3+ cells $[10,11]$ Nevertheless, the molecules involved in T-cell homing to conjunctiva, during the acute forms of AC in humans, are not fully studied yet. The aim of this study was to characterize the immunophenotypical features of circulating helper $\mathrm{T}$ cells, associated with Treg phenotype and homing receptors, in patients with perennial allergic conjunctivitis.

\section{Methods}

2.1. Patients. 21 individuals ( 12 males and 9 females, mean age 11.3 years, range 5-17) with active perennial allergic conjunctivitis (PAC) were studied. Perennial allergic conjunctivitis diagnosis was based on clinical history (mean disease duration 3.5 (SD 3.1) years) and eye and physical examination. Seven healthy volunteers were used as controls (4 males and 3 females, mean age 10.2 years, range 715). All participants gave their informed/assent consent for blood sampling after written information was provided. The study adhered to the ethical principles of the Declaration of Helsinki, the E11 Statements of International Conference of Harmonisation (E11-ICH), and was approved by the Institutional Ethics Committee Board at the Institute of Ophthalmology "Fundación Conde de Valenciana", Mexico City.

2.2. Monoclonal Antibodies and Reagents. Phycoerythrin (PE) labelled-mouse monoclonal antibodies (mAbs) against human CD25, CD103, CD108, IL-5; PECy5-labelled mAbs anti-human CD4; and fluorescein isothiocyanate (FITC)labelled antibodies against human FOXP3 were purchased from BD PharMingen (San Jose, CA, USA). FITC-labelled mAbs anti-human CCR9 and CCR7 and PE-labelled mAbs anti-human CCR4 were from R\&D Systems (Minneapolis, MN, USA). Allophycocyanin (APC)-labelled mAbs against CD4 were purchased from e-Biosciences (San Diego, CA, USA). Lymphoprep (Ficoll 1.077 density) was obtained from Nycomed Pharma (Nyegaard, Oslo, Norway). RPMI-1640 culture medium, Concanavalin A (Con A), PMA, ionomycin, saponin, brefeldin-A, and salts were from Sigma Chemical Co. (St. Louis, MO, USA). Sodium pyruvate, L-glutamine, and 2-mercaptoethanol were purchased from Gibco BRL (Rockville, MD, USA). Fetal calf serum was from HyClone Labs (Logan, UT, USA), Dermatophagoides pteronyssinus (Der $p$ ) was purchased from Allerstand Co. (Mexico, DF, MEX).
2.3. Peripheral Blood Mononuclear Cells. Whole heparinized peripheral blood was diluted 1:2 ( $\mathrm{vol} / \mathrm{vol})$ in phosphate buffered saline (PBS), pH 7.2. Peripheral blood mononuclear cells (PBMC) were separated on a Ficoll density gradient by centrifugation at $1700 \mathrm{rpm}$ for $30 \mathrm{~min}$ at room temperature. After centrifugation, the cells in the interface were collected, washed twice, and counted using a handheld automated cell counter (Millipore Co., Billerica, MA, USA), and viability was assessed by eosin dye exclusion.

2.4. Immunofluorescence Staining of Cell Surface Markers. Double or triple-colour staining was performed on PBMC by direct immunofluorescence, using APC- or PECy5-mAb anti-CD4 and either FITC- and/or PE-labelled mAbs against CD25, CD103, CD108, CCR4, CCR7, or CCR9. Briefly, $2 \times 10^{5}$ cells were suspended in $20 \mu \mathrm{L}$ PBS supplemented with $0.2 \%$ bovine serum albumin and $0.2 \%$ sodium azide (PBA) and were incubated with fluorochrome-labelled $\mathrm{mAb}$ for $30 \mathrm{~min}$ at $4^{\circ} \mathrm{C}$. After incubation, the cells were washed twice with PBA, fixed with $1 \%$ p-formaldehyde, and analysed by flow cytometry.

2.5. Immunofluorescence Staining of Intracellular Markers. Stimulated or nonstimulated PBMC were washed with PBA and stained with APC- or PECy5 labelled mAbs against CD4 and/or PE labelled mAbs against CD25 for $30 \mathrm{~min}$. After washing, the cells were fixed with $4 \% \mathrm{p}$-formaldehyde in PBS for $10 \mathrm{~min}$ at $4^{\circ} \mathrm{C}$. The cells were washed twice with PBS and permeabilised with saponin buffer $(0.1 \%$ saponin and $10 \%$ BSA in PBS) by shaking gently for $10 \mathrm{~min}$ at room temperature. The cells were then incubated with FITClabelled anti-human FOXP3 antibodies and/or PE-labelled anti-human IL-5. In all cases isotype-matched controls were used.

2.6. Cell Cultures. PBMC were cultured in 96-well flat bottomed cell culture plates (Costar, Cambridge, MA, USA) at $2 \times 10^{5}$ cells/well in RPMI-1640 medium supplemented with $1 \mathrm{mM}$ sodium pyruvate, $2 \mathrm{mM}$ L-glutamine, $50 \mu \mathrm{g} / \mathrm{mL}$ gentamicin, and $0.5 \%$ heat-inactivated fetal calf serum and incubated at $37^{\circ} \mathrm{C}$ in a $5 \% \mathrm{CO}_{2}$ humidified chamber. After $24 \mathrm{~h}$ the culture medium was removed, and fresh culture medium supplemented with $10 \%$ heat-inactivated fetal calf serum and $\operatorname{Der} p(7.5 \mu \mathrm{g} / \mathrm{mL})$ were added. After 7 days of culture, the cells were harvested and processed to measure intracellular FOXP3 expression, and homing receptors on cell surface by flow cytometer. The Con A mitogen $(2 \mu \mathrm{g} / \mathrm{mL})$ was used as a cell stimulation positive control. Supernatants were collected and stored at $-70^{\circ} \mathrm{C}$ to determine soluble cytokines. In order to determine intracellular IL-5, four hours before antigen or polyclonal cultures ended, brefeldin-A was added $(10 \mu \mathrm{g} / \mathrm{mL})$, and at the end of the incubation period the cells were harvested and were processed to immunofluorescence staining as described above.

2.7. Flow Cytometric Analysis. All cells were analysed for the expression of phenotypic markers on a FACScan flow cytometer (Becton Dickinson, San Jose, CA) using cell quest 
software, and 10000 events were counted. To analyse the staining of cell-surface markers, the lymphocytes were first gated by their physical properties (forward and side scatter), then a second gate was drawn based on immunofluorescence characteristics of the gated cells, assessing fluorescence intensity by histograms. To determine Tregs the cells were gated on FSC-SSC dot plot, then the lymphocytes were gated on CD4+ $\mathrm{T}$ cells in a SSC-CD4 dot plot, then CD4+ cells were selected, and a CD4-CD25 dot plot was created to select, the double positive $\mathrm{CD} 4+\mathrm{CD} 25+\mathrm{T}$ cells; finally to analyse intracellular FOXP3 staining on CD4+CD25+ T cells a histogram was created to analyse the mean fluorescence intensity (MFI) of FOXP3+ cells. Data are presented as dot-plots or histograms. Control stains were performed using isotype-matched $\mathrm{mAb}$ of unrelated specificity. Background staining was $<1 \%$ and was subtracted from experimental values.

2.8. Determination of Soluble Cytokines. IL-1b, IL-6, IL-8, IL10, IL-12p70, and TNF- $\alpha$ (Human Inflammation Cytokine Kit. BD Biosciences, Franklin Lakes, NJ, USA) were measured with cytometric bead arrays (CBA) in supernatants samples according to manufacturer's instructions (BD Biosciences) and analysed by flow cytometry with BD cytometric bead array software version 1.1.1 (Becton Dickson).

2.9. Statistical Analysis. Mann-Whitney $U$ tests or Wilcoxon Rank Signed test was used to detect significant differences. The analysis was performed with Graphpad Prism software v.5.0. Differences were considered statistically significant when the test yielded $P$ values less than 0.05 .

\section{Results}

3.1. Frequency of CD25+ Cells and CD4+CD25+FOXP3+ Regulatory T Cells in Peripheral Blood Mononuclear Cells. We began by determining the percentage of CD25+ and $\mathrm{CD} 4+\mathrm{CD} 25+\mathrm{T}$ cells in the peripheral blood of 14 patients with allergic conjunctivitis and 7 healthy controls. As expected, the percentage of CD4+ T cells were similar among patients with perennial allergic conjunctivitis (PAC) and healthy controls (HC) (MD 27\%, IQR 24-30 versus MD 34\%, IQR 28-35, resp.; $P=0.07$ ); meanwhile, the frequency of CD25+ cells was significantly increased in patients with PAC compared to HC (MD 5\%, IQR 2.9-8.2 versus MD 0.1\%, IQR $0.07-1.5$, resp.; $P=0.001$ ). Likewise, the percentage of CD4+ $\mathrm{T}$ cells expressing CD25 were also significantly increased in patients with PAC in comparison to HC (MD 18.6\%, IQR 7.2-22 versus MD 0.5\%, IQR 0.4-1.7, resp.; $P=0.0006$ ) (Figures 1(a) and 1(b)). When we analysed the frequency of FOXP3 on CD4+CD25+ gated cells, the majority of the CD25+ helper cells were FOXP3- in both PAC and HC groups (MD 3.4\% IQR 1-7 versus MD 1.8\% IQR 0.4-9, resp.; $P=0.5$ ) (Figure 1(c)). Interestingly, MFI in FOXP3+ cells from patients with PAC was significantly decreased when it was compared with MFI in FOXP3+ cells from HC (MFI $17 \pm 9$ versus MFI $93 \pm 13$, resp.; $P<0.0001$ ) (Figure $1(\mathrm{c})$ ).
3.2. Frequency of Chemokine Receptors on Peripheral Blood Mononuclear Cells. To determine whether chemokine receptor expression was associated with a particular $\mathrm{T}$ helper cell traffic molecule in patients with PAC, CCR4, CCR7, and CCR9 was measured on PBMC. Results are summarized in Table 1. It was observed that CCR4+ cells were 1.9 times more frequent on PBMC from patients with PAC than in $\mathrm{HC}(P=$ 0.004). Most of the CCR4+ cells were CD4+ T cells, and CD4+CCR4+ cells were 1.8 times more frequent in patients with PAC than in HC $(P=0.03)$ (Figures $2(a)$ and $2(\mathrm{~d}))$. We did not observe differences in frequency of CCR7+ or CCR7- cells neither on PBMC nor on CD4+ cells among groups (Figures 2(b) and 2(e)). The CCR9+ cells were 4.2 times more frequent on PBMC from patients with PAC than in $\mathrm{HC}(P=0.01)$, and the $\mathrm{CD} 4+\mathrm{T}$ cells expressing CCR9 were 2.5 times more frequent in patients with PAC than in HC $(P=0.01)$ (Figures 2(c) and 2(f)) (Table 1).

\subsection{Frequency of $C D 4+C D 25+F O X P 3+$ Regulatory $T$ Cells} and Cell-Migration Receptors after Dermatophagoides pteronyssinus (Der p)-Stimulation. To establish the potential involvement of the specific antigenic-stimulation in the expression of FOXP3 and in the upregulation of cell migration receptors in PBMC from patients with PAC, we assessed the percentage of CD4, CD25, FOXP3, CCR4, CCR7, CCR9, CD103, and CD108 after Derp stimulation in 7 patients with active perennial allergic conjunctivitis. The specific allergic condition to Der $p$ was confirmed by a skin-prick test positive to $\operatorname{Der} p$ (wheal, $>3 \mathrm{~mm}$ diameter) and determination of IgE specific to Der p1 $(49.8 \pm 39.5 \mathrm{kU} / \mathrm{L})$. After allergenstimulation, we observed a significant increase in the percentage of CD25+ cells $(P=0.0007)$ and $\mathrm{CD} 4+\mathrm{CD} 25+$ cells $(P<0.0001)$ (Figures 3(a) and 3(b)); and although frequency of $\mathrm{CD} 4+\mathrm{CD} 25+\mathrm{FOXP} 3+$ regulatory $\mathrm{T}$ cells was increased 7-folds when compared with nonstimulated cells $(P<0.0001)$ (Figure 3(c)), we did not observe significant differences between the frequency of FOXP3+ versus that of FOXP3 - subsets on gated CD4+CD25+ cells after specific stimuli (Figure 3(d)). Afterwards, we analysed the frequency of chemokine receptors positive cells, and 1.9 times more CCR9+ cells $(P=0.04)$ and 2.5 times more CD4+CCR4+CCR9+ cells were observed $(P=0.01)$ after Der p-stimulation (Table 2). No significant changes were observed in the percentage of the following cell subsets: CCR4+, CD4+CCR4+, CCR7+, CCR7-CD4+CCR7+, and CD4+CCR7- cells. Moreover, we observed 4.1-fold more CD4+CD103+ cells $(P=0.007)$ (Figure 4$), 2.5$-fold more CD108+ cells $(P=0.01)$, and 4.9-fold more CD4+CD108+ cells $(P=0.01)$ after allergen specific stimulation (Figure 5). Results are summarized in Table 2.

3.4. Cytokines after Der p-Stimulation. The levels of secreted cytokines IL-1b, IL-6, IL-8, IL-10, IL-12p70, and TNF- $\alpha$ were determined in culture supernatants after $\operatorname{Der} p$-stimulation. IL- 6 and IL-8 were significantly increased when compared with nonstimulated cells $(P=0.01$ and $P=0.04$, resp.). Results are depicted in Table 3 . In order to know if 
TABLE 1: Frequencies of chemokine receptors in patients with PAC and HC.

\begin{tabular}{lccc}
\hline Chemokine receptor & Patients with PAC & Healthy controls & $P$ \\
& MD (IQR-Range) & MD (IQR-Range) & 0.004 \\
CCR4+ & $19 \%(15.8-40.6)$ & $10 \%(9.6-14.2)$ & 0.688 \\
CCR7+ & $35 \%(17-47.7)$ & $67 \%(62.6-70.8)$ & 0.688 \\
CCR7- & $65 \%(52.3-83)$ & $4 \%(3.9-6.5)$ & 0.01 \\
CCR9+ & $18 \%(8-29.8)$ & $23 \%(20.8-43.8)$ & 0.03 \\
CD4+CCR4+ & $42 \%(31.1-53.8)$ & $61 \%(24.8-76)$ & 0.433 \\
CD4+CCR7+ & $67 \%(45.6-77.6)$ & $39 \%(24-75.2)$ & 0.433 \\
CD4+CCR7- & $33 \%(22.4-54.4)$ & $4 \%(3.8-6.5)$ & 0.01 \\
CD4+CCR9+ & $18 \%(8-29.8)$ & & \\
\hline
\end{tabular}

MD: Median, IQR: Interquartile range.

TABLE 2: Frequencies of cell-subsets and cell-migration receptors after Der p-stimulation.

\begin{tabular}{|c|c|c|c|c|c|}
\hline \multirow{2}{*}{ Cell-subsets } & \multirow{2}{*}{$\begin{array}{c}\text { RPMI } \\
\text { MD (IQR-Range) }\end{array}$} & \multirow{2}{*}{$\begin{array}{c}\operatorname{Der} p \\
\text { MD (IQR-Range) }\end{array}$} & \multirow{2}{*}{$\begin{array}{l}\text { Con A mitogen } \\
\text { MD (IQR-Range) }\end{array}$} & \multicolumn{2}{|c|}{$P$} \\
\hline & & & & RPMI versus $\operatorname{Der} p$ & Der $p$ versus Con A \\
\hline CD25+ & $12.5 \%(10.9-15.7)$ & $20.4 \%(16.0-26.4)$ & $87.5 \%(78.2-93.4)$ & 0.001 & $<0.0001$ \\
\hline $\mathrm{CD} 4+\mathrm{CD} 25+$ & $16.2 \%(12.5-20.8)$ & $28.2 \%(23-32.7)$ & $99.4 \%(99-99.5)$ & 0.0004 & $<0.0001$ \\
\hline $\begin{array}{l}\text { CD } 4+C D 25+ \\
\text { F0XP3+ }\end{array}$ & $3.5 \%(1.8-14.9)$ & $57 \%(50-63.5)$ & $18 \%(12.8-28.4)$ & $<0.0001$ & $<0.0001$ \\
\hline CCR4+ & $19 \%(13.2-28)$ & $21 \%(16-27.6)$ & $69 \%(56.6-80.2)$ & 0.312 & 0.002 \\
\hline CCR7+ & $55 \%(41.5-63.5)$ & $49 \%(36-56.9)$ & $84 \%(72.1-88.2)$ & 0.687 & 0.0006 \\
\hline CCR7- & $45 \%(36.5-58.5)$ & $51 \%(43.1-64)$ & $16 \%(11.8-27.9)$ & 0.687 & 0.0006 \\
\hline CCR9+ & $1 \%(0.5-2.2)$ & $2 \%(1.9-9.9)$ & $3.4 \%(2.9-7.6)$ & 0.04 & 0.62 \\
\hline CD4+CCR4+ & $32 \%(21.6-50.7)$ & $32 \%(24.8-45.3)$ & $91 \%(84.7-97.5)$ & 0.62 & 0.001 \\
\hline CD4+CCR7+ & $86 \%(79.7-89.1)$ & $82 \%(74.2-86.9)$ & $98 \%(95.0-98.5)$ & 0.06 & 0.0006 \\
\hline CD4+CCR7- & $14 \%(10.9-20.3)$ & $18 \%(13.1-25.8)$ & $2 \%(1.5-5.0)$ & 0.06 & 0.0006 \\
\hline CD4+CCR9+ & $1 \%(0.6-3.4)$ & $4 \%(2.5-19.5)$ & $3.7 \%(2.9-6.6)$ & 0.15 & 0.62 \\
\hline $\begin{array}{l}\text { CD } 4+C C R 4+ \\
\text { CCR9+ }\end{array}$ & $5.2 \%(2.5-5.5)$ & $13 \%(10-42.7)$ & $6 \%(5.4-9.8)$ & 0.01 & 0.01 \\
\hline CD103+ & $4 \%(2.6-7.5)$ & $6 \%(4.0-7.1)$ & $33 \%(26.0-34.2)$ & 0.295 & 0.001 \\
\hline CD108+ & $9 \%(30-14.4)$ & $23 \%(15.6-35.5)$ & $76 \%(63.8-76.7)$ & 0.01 & 0.0003 \\
\hline $\mathrm{CD} 4+\mathrm{CD} 103+$ & $2 \%(0.9-2.8)$ & $7 \%(3.3-11.0)$ & $38 \%(13.8-57.2)$ & 0.007 & 0.001 \\
\hline $\mathrm{CD} 4+\mathrm{CD} 108+$ & $6 \%(1.3-7.6)$ & $27 \%(14.5-29.9)$ & $76 \%(69.7-84.8)$ & 0.01 & 0.002 \\
\hline
\end{tabular}

MD: Median; IQR: Interquartile range.

TABLE 3: Cytokines concentration in supernatants of cell culture.

\begin{tabular}{|c|c|c|c|c|c|}
\hline & \multirow{2}{*}{$\begin{array}{c}\text { RPMI } \\
\text { MD (IQR-Range) }\end{array}$} & \multirow{2}{*}{$\begin{array}{c}\operatorname{Der} p \\
\text { MD (IQR-Range) }\end{array}$} & \multirow{2}{*}{$\begin{array}{c}\text { Con A } \\
\text { MD (IQR-Range) }\end{array}$} & \multicolumn{2}{|c|}{$P$} \\
\hline & & & & RPMI versus $\operatorname{Der} p$ & $\operatorname{Der} p$ versus Con A \\
\hline IL-1 $\beta$ & $\begin{array}{c}55.6 \\
(50.2 \pm 63.6)\end{array}$ & $\begin{array}{c}52.4 \\
(44.3 \pm 67.9)\end{array}$ & $\begin{array}{c}115 \\
(96.9 \pm 205)\end{array}$ & 0.99 & 0.01 \\
\hline IL-6 & $\begin{array}{c}118.9 \\
(72.3-291.2)\end{array}$ & $\begin{array}{c}480.6 \\
(284 \pm 515.3)\end{array}$ & $\begin{array}{c}2554 \\
(1724 \pm 6239)\end{array}$ & 0.01 & 0.001 \\
\hline IL-8 & $\begin{array}{c}13579 \\
(11145 \pm 14853)\end{array}$ & $\begin{array}{c}14753 \\
(14332 \pm 18661)\end{array}$ & $\begin{array}{c}12657 \\
(11094 \pm 14287)\end{array}$ & 0.04 & 0.01 \\
\hline IL-10 & $\begin{array}{c}62.51 \\
(55.9-104.9)\end{array}$ & $\begin{array}{c}69.1 \\
(60.8-175.4)\end{array}$ & $\begin{array}{c}243 \\
(173-324)\end{array}$ & 0.32 & 0.09 \\
\hline IL-12p70 & $\begin{array}{c}51.6 \\
(50.5-63.9)\end{array}$ & $\begin{array}{c}48.1 \\
(46.4-49.2)\end{array}$ & $\begin{array}{c}4458 \\
(2077-6951)\end{array}$ & 0.06 & 0.001 \\
\hline TNF- $\alpha$ & $\begin{array}{c}34.9 \\
(33.0-61.8)\end{array}$ & $\begin{array}{c}32.3 \\
(31.23-34.7)\end{array}$ & $\begin{array}{c}6942 \\
(4070-19610)\end{array}$ & 0.07 & 0.0007 \\
\hline
\end{tabular}

MD: Median; IQR: Interquartile range.

Results are in pg/mL; kit detection limits were as follows: IL-1 $\beta: 3.7$ pg/mL; IL-6: 4.7 pg/mL; IL-8: 3.4 pg/mL; IL-10: 4.1; IL-12p70: 4.0; TNF- $\alpha$ : 3.9 pg/mL. 

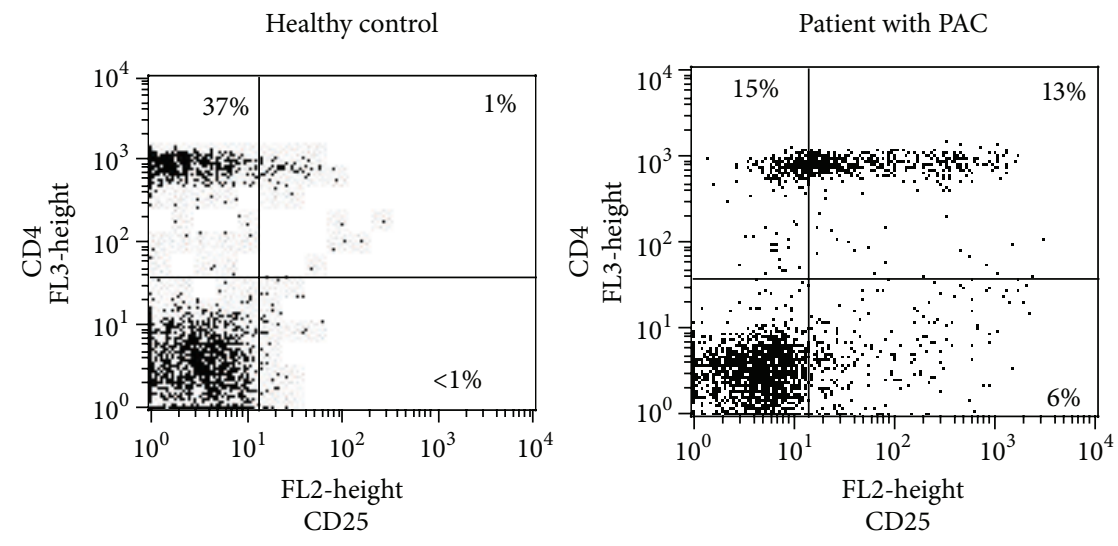

(a)
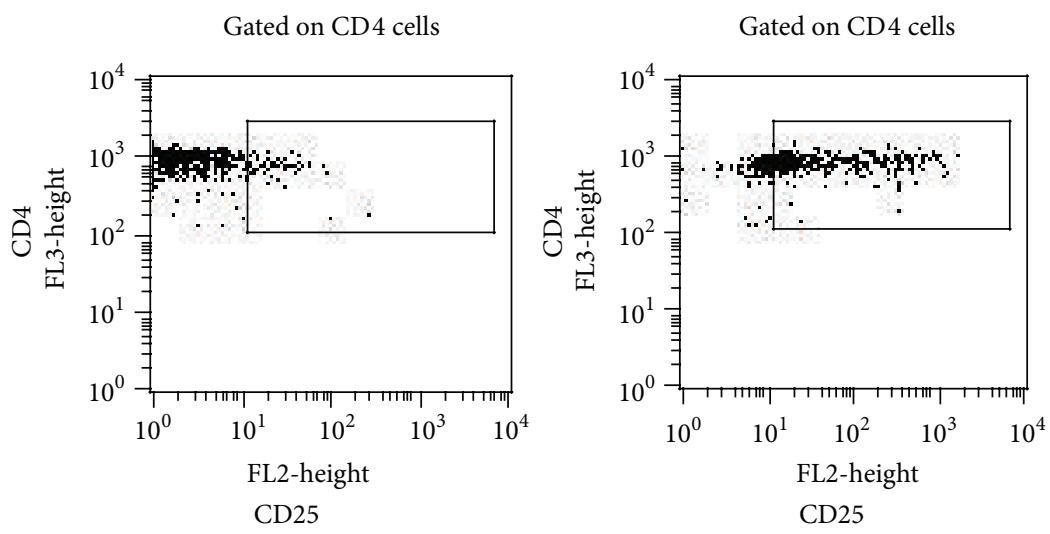

(b)
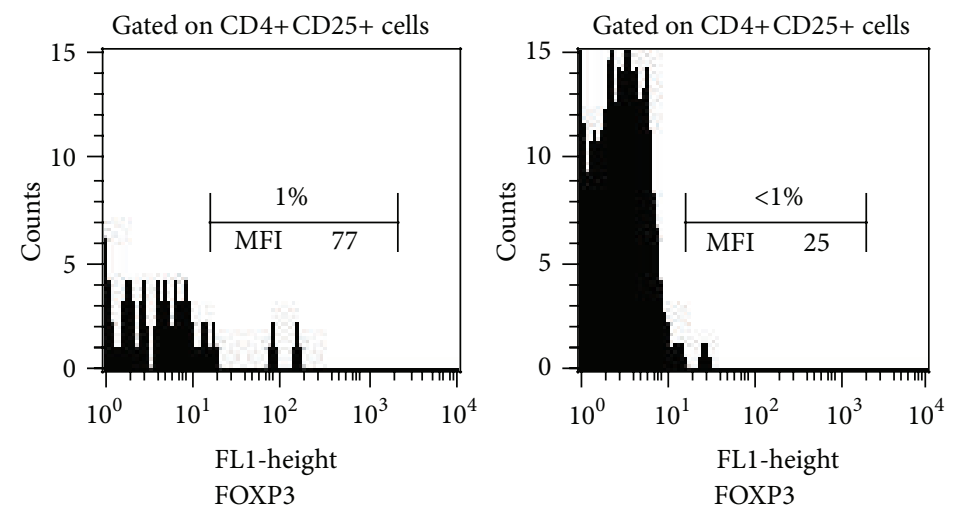

(c)

Figure 1: Frequency of CD25+ cells and CD4+CD25+FOXP3+ regulatory T cells in peripheral blood mononuclear cells. (a) Frequency of CD4+, CD25+, and double positive to CD4+CD25+ cells in PBMC from HC and PAC patient. (b) Same dot plot as (a); CD4+ cells gated as previously described in materials and methods, showing a gate performed to analyse CD4+CD25+ double positive cells. (c) Histogram from $\mathrm{CD} 4+\mathrm{CD} 25+$ gated cells (gated in (b)); the $x$-axis denotes FOXP3 (MFI = mean fluorescence intensity). These dot plots and histograms are representative of $7 \mathrm{HC}$ and 14 PAC patients.

$\operatorname{Der} p$-stimulation induced early secretion of IL-5 in CD4+ cells, we performed intracellular evaluation of IL-5 in CD4+ T cells from patients with PAC. We observed 10.3 times more frequency of CD4+IL-5+ cells after Der-p stimulation when compared with RPMI alone (Mean 15.5\% SD 3.6 versus Mean $1.4 \%$ SD 3, resp.; $P=0.02$ ) (Figure 6).

\section{Discussion}

Allergic conjunctivitis is an inflammation of the conjunctiva secondary to an immune response caused by contact with an allergen at the bulbar or tarsal conjunctiva in a previously sensitized individual [12]. Two types of AC have been described, 


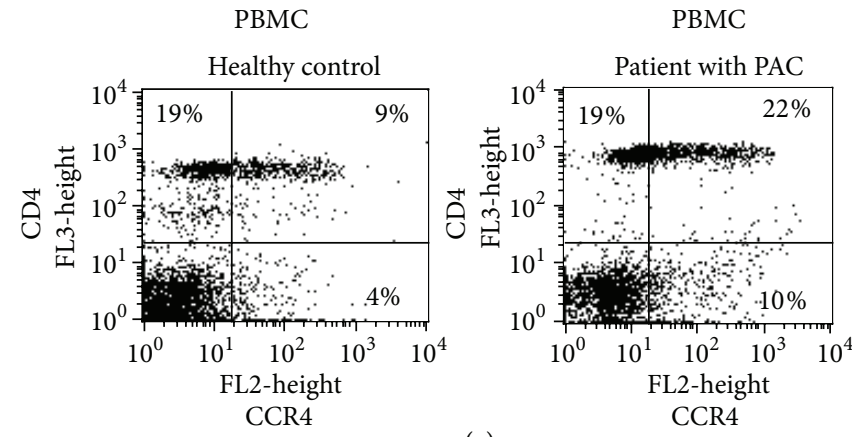

(a)
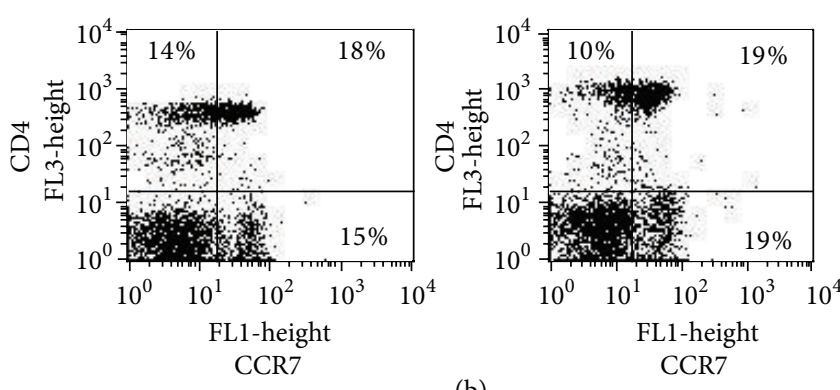

(b)
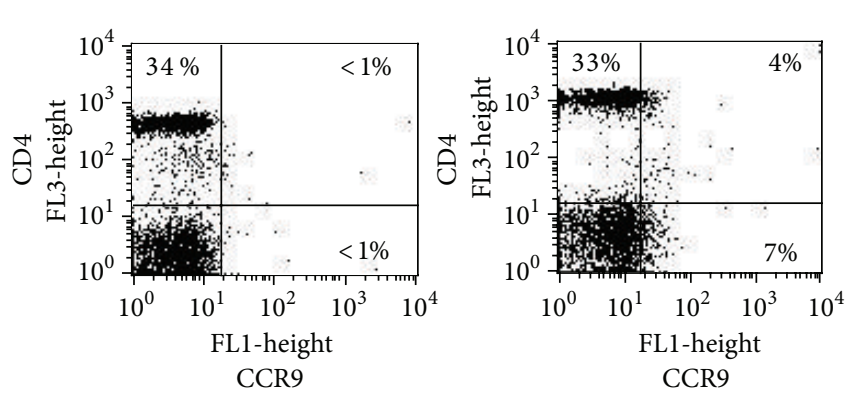

(c)
Gated on CD4+ T cells
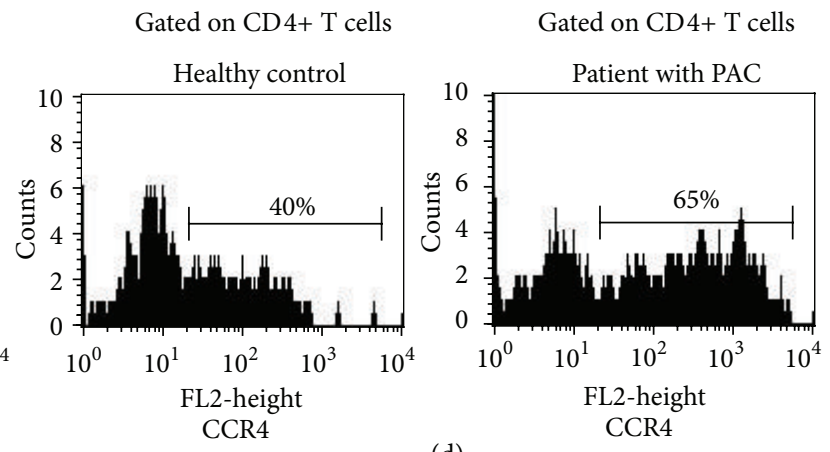

(d)
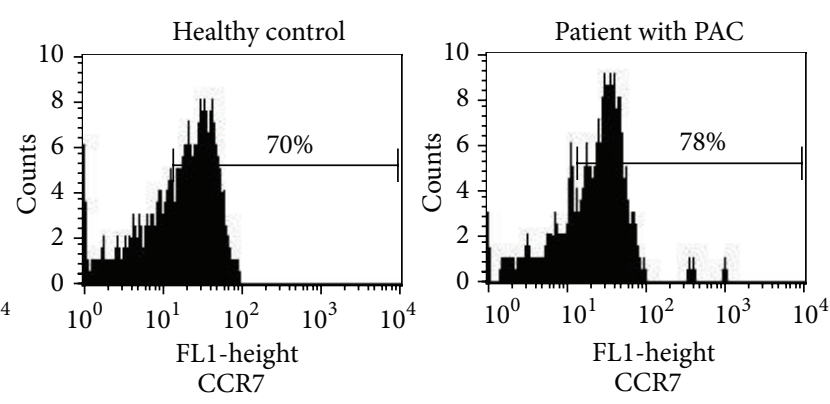

(e)
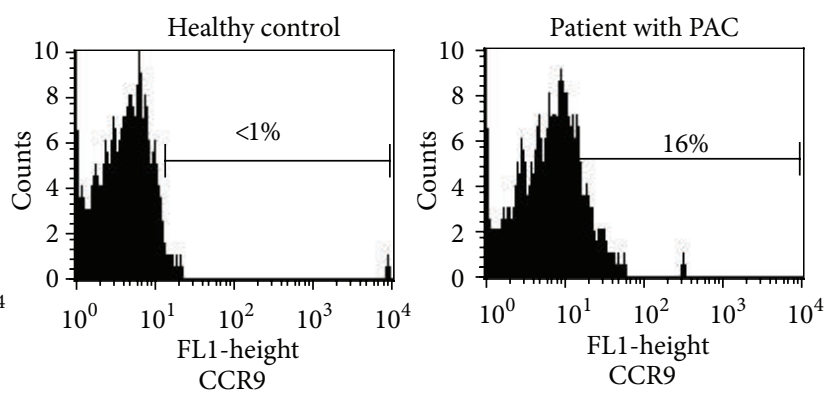

(f)

FIGURE 2: Frequency of chemokine receptors positive cells on circulating PBMC from healthy controls (HC) and from patients with perennial allergic conjunctivitis (PAC) PBMC were stained with fluorescence-conjugated antibodies to CD4 and (a) CCR4, (b) CCR7, and (c) CCR9, in a double-immunofluorescence assay, as described in materials and methods. Representative histograms of CD4+ gated cells are shown (d) CD4+CCR4+, (e) CD4+CCR7+, and (f) CD4+CCR9+ cells in both, HC and patients with PAC. Representative dot plots and histograms from $7 \mathrm{HC}$ and 14 PAC.

the acute forms and the chronic forms; acute forms included $\mathrm{SAC}$ and $\mathrm{PAC}$ and are the most frequent types of $\mathrm{AC}$ and are clinically characterized by itching, redness, and tearing $[2,3,12,13]$; VKC and AKC are the chronic forms and they could lead to permanent visual impairment due to persistent inflammation $[13,14]$. In the chronic forms of AC, allergenmediated inflammation is maintained by infiltrating CD4+ cells to conjunctiva [15]; migration of effector cells (T cells and non-T cells) is dependent of CCR3 and CXCR3 expression $[10,11]$. In acute forms of AC, molecules involved in CD4 recruitment have not been enough studied. In mice models of $\mathrm{AC}$, induction of $\mathrm{CD} 4+\mathrm{CD} 25+\mathrm{FOXP} 3+$ regulatory $\mathrm{T}$ cells suppresses effector-cell activation through synthesis of IL-10 and TGF-b [7]; nonetheless, the frequency of Tregs in patients with AC has not been described yet.

In this work we analysed the frequency of circulating Tregs and the frequency of cells expressing molecules involved in T-cell homing to mucosa inflammation, in patients with perennial allergic conjunctivitis. Our results are in accordance with other authors [16-19] that have reported changes in frequency of $\mathrm{CD} 4+\mathrm{CD} 25+\mathrm{T}$ cells and CD4+CD25+FOXP3+ regulatory $\mathrm{T}$ cells in atopic diseases, such as asthma, rhinitis, and atopic dermatitis [16-19]. These authors suggest that changes in the frequency of Tregs or impairment of their regulatory capacity could be associated with the activation of allergic status. In this work, the majority of CD4+CD25+ cells were FOXP3- cells; and after allergen-stimulation, no differences were observed among the frequency of FOXP3+ cells and FOXP3- cells; this result is relevant since it is well known that IL-6 is able to suppress Treg differentiation [20]. It is possible that after encountering with the antigen, allergen-specific $\mathrm{CD} 4+\mathrm{T}$ cells from PAC patients would be able to secrete IL-6, as it was observed after in vitro stimulation, interfering with $\mathrm{CD} 4+\mathrm{CD} 25+\mathrm{FOXP} 3+$ 


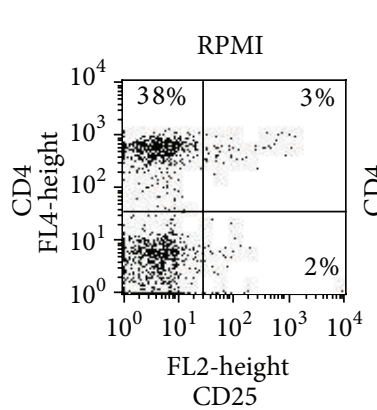

CD25

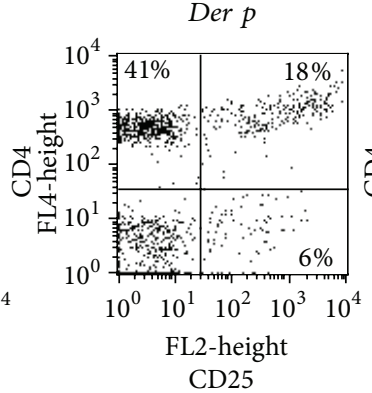

(a)

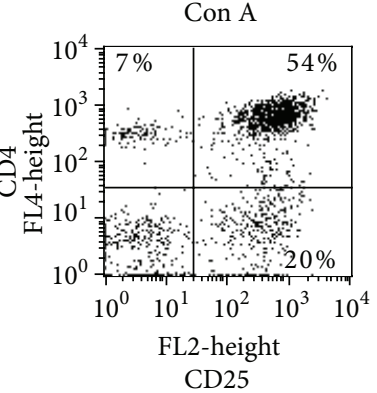

CD25

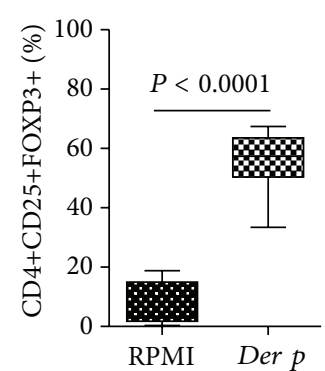

(c)

Gated on CD4+CD25+ cells

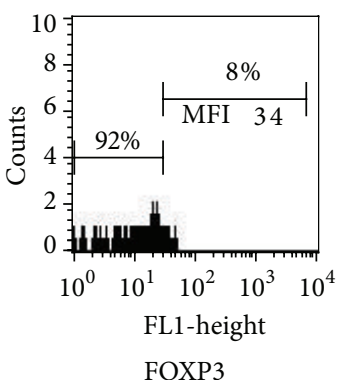

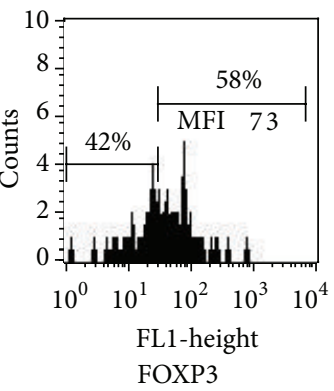

(b)

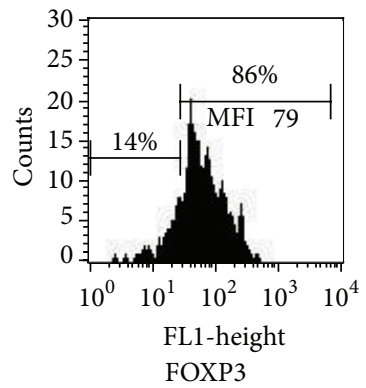

FOXP3

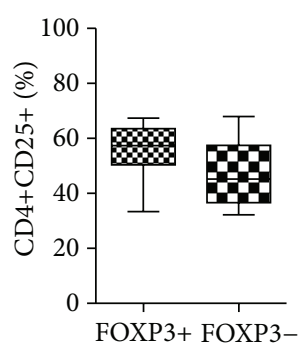

(d)

Figure 3: Frequency of CD25+ cells and CD4+CD25+FOXP3+ regulatory T cells after stimulation. (a) Representative dot plots of PBMC stimulated with Der $p$ or Con A in patients with PAC. (b) Comparative histograms of FOXP3+ frequency on CD4+CD25+ gated cells. The $x$-axis denotes the mean fluorescence intensity (MFI) of FOXP3. (c) Significant differences were observed in the frequency of Tregs upon Der p-stimulation. (d) Distribution of FOXP3+ and FOXP3- cell subsets on CD4+CD25+ gated cells after allergen-stimulation.

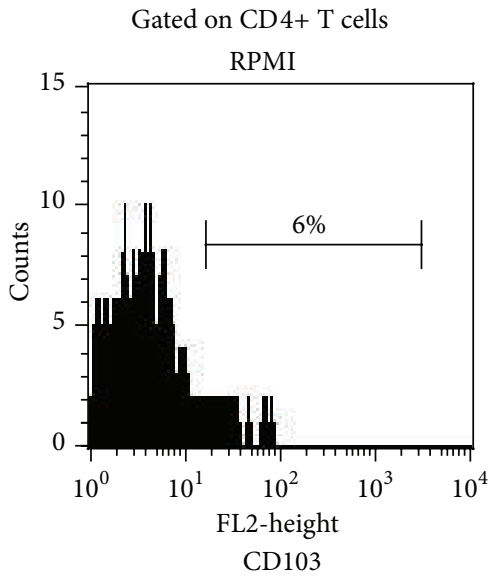

(a)

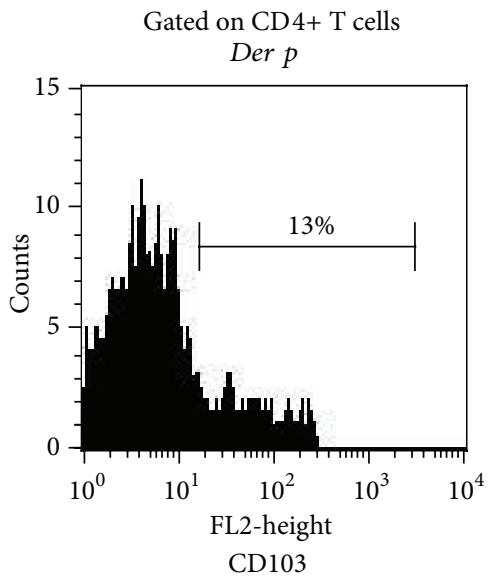

(b)

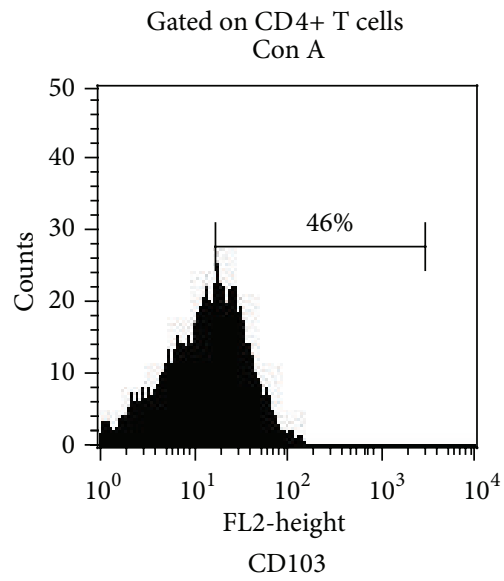

(c)

Figure 4: Increased frequency of CD4+CD103+ T cells after allergen-stimulation. (a) RPMI (nonstimulated cells, culture medium). (b) Der p-stimuli. (c) Con A mitogen (Positive stimulation control); $x$-axis denotes frequency of CD103+ cells on CD4+ gated cells from patients with PAC. Representative histograms of CD4+CD103+ T cells are shown.

differentiation, since it has been described that Treg cell differentiation requires antigen stimulation by engagement $\mathrm{T}$ cell receptor to induce FOXP3 expression [21]. Supporting this idea, the induction of FOXP3 by Con A-stimulation could be explained because of the polyclonal activation through mannose ligands on PBMC by Con A $[22,23]$; nevertheless, FOXP3+ cells induced by Con A are mainly NnTregs, a different T cell subset of Tregs [24, 25].

On the other hand, it has been described that CD25 is the alpha subunit of IL2R and its expression has been related to 


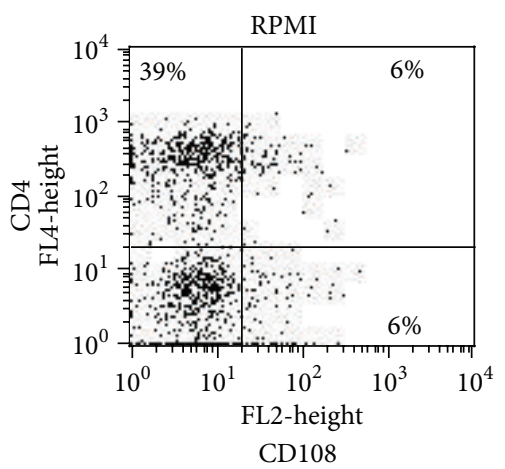

(a)

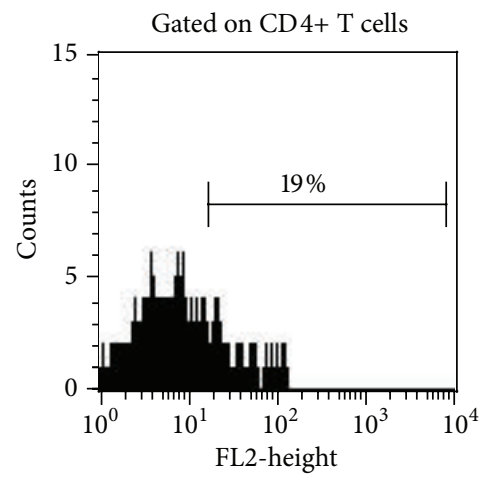

CD108

(d)

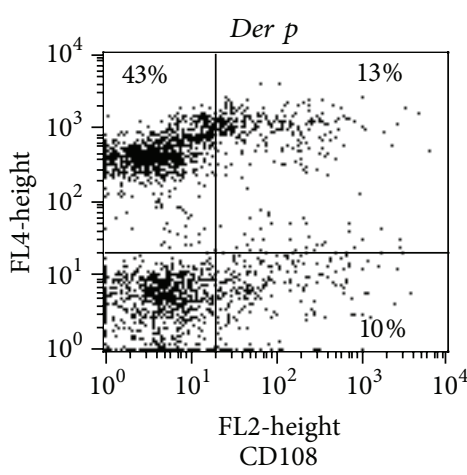

(b)

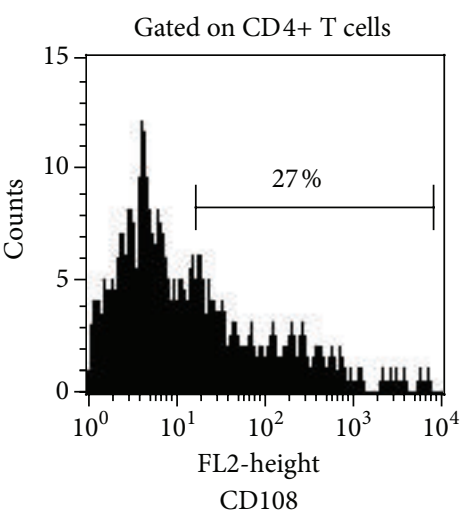

(e)

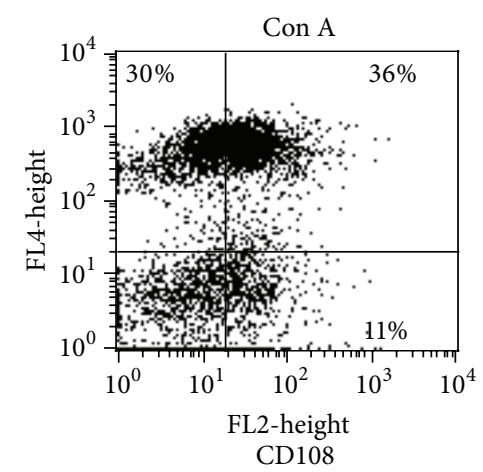

(c)

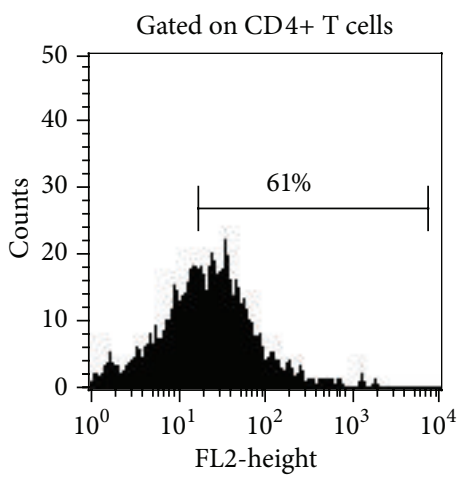

CD108

(f)

FIGURE 5: Increased frequency of CD108+ cells after allergen-stimulation. Representative dot plots of (a) nonstimulated cells, (b) Der pstimulated cells, and (c) Con A-stimulated cells. Representative histograms of CD4+ gated cells, (d) nonstimulated cells, (e) Der p-stimulated cells, and (f) Con A-stimulated cells; $x$-axis denotes fluorescence to CD108 on CD4+ gated cells.

activation status of T cells [26]; interestingly, in this study, the frequency of PBMC expressing this cell surface marker was significantly elevated in PAC patients group in contrast to healthy individuals, suggesting that PBMC and circulating $\mathrm{CD} 4+\mathrm{T}$ cells are in an activation status, as similarly reported in other allergies like asthma [27, 28] rhinitis [28], and dermatitis [29].

A differential expression of chemokine receptors was observed in patients with PAC; most CD4+ T cells were CCR4+ cells, and CCR9+ cells. These findings are remarkable, as CCR4 is known to modulate T-cell migration to sites of allergic-mediated inflammation in asthma and rhinitis $[30,31]$; CCR4+ cells are also an important source of IL4 and other Th2 cytokines [30, 31]. CCR9 is a molecule expressed on antigen-experienced memory $\mathrm{T}$ cells and it was described as a chemokine marker related to mucosalhoming [32]. It is possible that circulating CD4+CCR4 and/or CD4+CCR9+ cells observed in PBMC from our patients are cell-subsets in transit to conjunctiva, since after allergen-stimulation increased significantly the percentage of CD4+CCR4+CCR9+ cells. Remarkably, IL-4 is required for CCR9 imprinting on CD4+ T cells [33], and it is recognized that IL-4 and IL-5 are induced after Der $p$ stimulation in allergic patients and promote allergic status [5].

HML-1 or CD103 ( $\alpha_{E} \beta_{7}$ integrin) was first described as a molecule related to mucosal migration [34], and the vast majority of intraepithelial lymphocytes are CD103+ cells [9]. HML-1 could be induced by epithelial cells on activated lymphocytes [35] and has been implicated in epithelial T-cell retention through binding to E-cadherin [36]. In the present study, upon allergen specific-stimulation it was observed an increased percentage of CD4+CD103+ T cells. The CD4+CD103+ cells have been proposed as regulatory $\mathrm{T}$ cell subset [37]. Likewise, after $\operatorname{Der} p$ stimulation, the percentage of CD108+ cells were significantly increased. The CD108 (Sema7a) is a glycosylphosphatidylinositol-anchored semaphorin and has been described as a molecule that initiates T-cell-mediated inflammatory response through interaction with alphalbetal integrin [38]. On the other hand, it has been proposed that CD108 exists as a complex with TCR and/or CD3 on $\mathrm{T}$ cell surface and after activation inhibits $\mathrm{T}$ cell signalling and decreases proliferation [39]. In this context, whether the expansion of these two subsets, $\mathrm{CD} 4+\mathrm{CD} 103+$ cells or CD4+CD108+ cells, is related to 

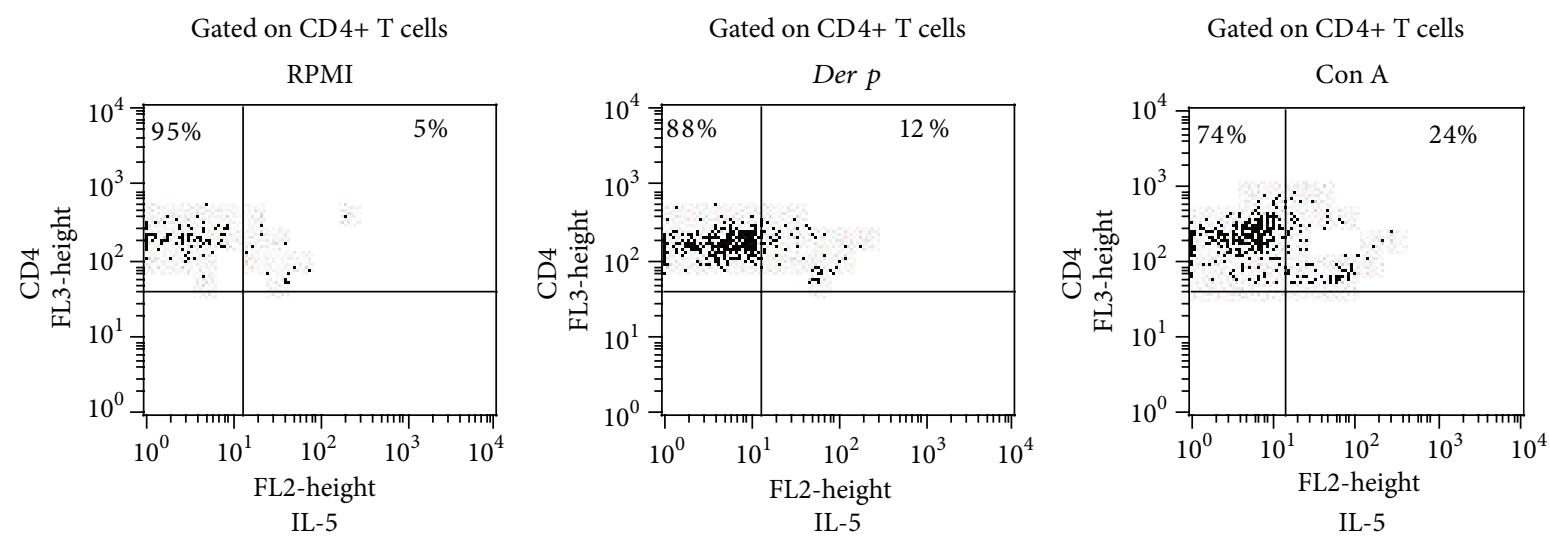

(a)

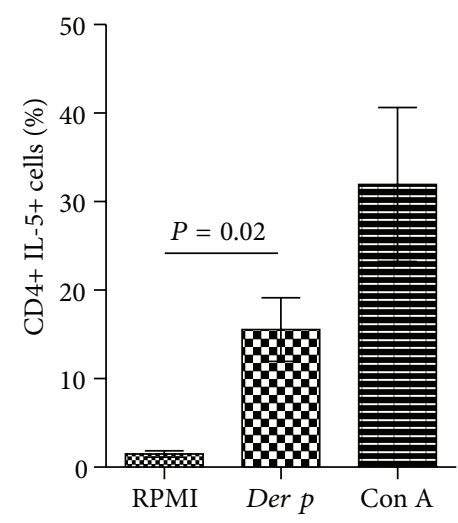

(b)

FIGURE 6: Frequency of CD4+ IL-5+ cells after Der p-stimulation. PBMC were Der p-stimulated for $72 \mathrm{~h}$ and stained for CD4 and intracellular IL-5 as described in materials and methods. (a) Left panel, nonstimulated cells, central panel, Der p-stimulated cells and right panel, and Con A-stimulated cells; representative dot plots from three PAC patients. (b) Comparison of the frequency of CD4+IL-5+ cells among different stimuli. Data are expressed as mean \pm SD.

mucosa-homing or corresponds to regulatory $\mathrm{T}$ cell subsets trying to counterbalance inflammatory CCR4+CCR9+ cell subsets and IL-6/IL-8 secretion is not known and needs further investigation.

The data shown here could lead to new perspectives in the treatment of the most frequent ocular condition seen by ophthalmologists and allergo/immunologists; CCR4 and CCR9 molecules could be used as potential targets for biological therapy in patients with PAC, as it has been proposed for asthma and the monoclonal anti-CCR4 antibody [40].

Taken together, it is possible that the interaction of CCR4, CCR9, and possibly CD103 and CD108 with their ligands secreted or expressed on activated endothelial cells and conjunctiva favours the selective adhesion of a circulating CD4+ $\mathrm{T}$ cell subset with an activated phenotype and the ability to respond to antigens, driving the immune-response to the ocular mucosa and inducing a proinflammatory microenvironment related to Th2 perennial allergic conjunctivitis.

\section{Conflict of Interests}

The authors declare that they have no conflict of interests.

\section{Acknowledgments}

Authors wish to thank Lizet Vizuet and Veronica Romero Martinez for their technical assistance. This work was supported in part by CONACYT 71291, Transfer Factor Project and Fundación Conde de Valenciana. J. Galicia-Carreón that received a $\mathrm{PhD}$ scholarship from CONACyT number 219848 and CVU 267996.

\section{References}

[1] N. G. Papadopoulos, I. Agache, S. Bavbek et al., "Research needs in allergy: an EAACI position paper, in collaboration with EFA," Clinical and Translational Allergy, vol. 2, no. 1, p. 21, 2012.

[2] D. Brémond-Gignac, "The clinical spectrum of ocular allergy," Current Allergy and Asthma Reports, vol. 2, no. 4, pp. 321-324, 2002.

[3] L. Bielory, "Allergic and immunologic disorders of the eye. Part I: immunology of the eye," Journal of Allergy and Clinical Immunology, vol. 106, no. 5, pp. 805-816, 2000.

[4] E. Maggi, “The TH1/TH2 paradigm in allergy,” Immunotechnology, vol. 3, no. 4, pp. 233-244, 1998. 
[5] Y. Garfias, B. Ortiz, J. Hernández et al., "CD4+CD30+ T cells perpetuate IL-5 production in Dermatophagoides pteronyssinus allergic patients," Allergy, vol. 61, no. 1, pp. 27-34, 2006.

[6] A. Leonardi, G. DeFranchis, F. Zancanaro et al., "Identification of local Th2 and Th0 lymphocytes in vernal conjunctivitis by cytokine flow cytometry," Investigative Ophthalmology and Visual Science, vol. 40, no. 12, pp. 3036-3040, 1999.

[7] A. Fukushima, T. Sumi, K. Fukuda et al., "Modulation of murine experimental allergic conjunctivitis by treatment with $\alpha$-galactosylceramide," Immunology Letters, vol. 107, no. 1, pp. 32-40, 2006.

[8] V. G. Bundoc and A. Keane-Myers, "IL-10 confers protection from mast cell degranulation in a mouse model of allergic conjunctivitis," Experimental Eye Research, vol. 85, no. 4, pp. 575-579, 2007.

[9] H. S. Dua, J. A. P. Gomes, L. A. Donoso, and P. R. Laibson, "The ocular surface as part of the mucosal immune system: conjunctival mucosa-specific lymphocytes in ocular surface pathology," Eye, vol. 9, part 3, pp. 261-267, 1995.

[10] A. M. Abu El-Asrar, S. Struyf, A. A. Al-Mosallam, L. Missotten, J. van Damme, and K. Geboes, "Expression of chemokine receptors in vernal keratoconjunctivitis," British Journal of Ophthalmology, vol. 85, no. 11, pp. 1357-1361, 2001.

[11] D. Miyazaki, T. Nakamura, N. Komatsu et al., "Roles of chemokines in ocular allergy and possible therapeutic strategies," Cornea, vol. 23, supplement 8, pp. S48-S54, 2004.

[12] L. Bielory, "Allergic and immunologic disorders of the eye. Part II: ocular allergy," Journal of Allergy and Clinical Immunology, vol. 106, no. 6, pp. 1019-1032, 2000.

[13] A. Robles-Contreras, A. Santacruz, J. Ayala et al., Allergic Conjunctivitis: An Immunological Point of View, ConjunctivitisA Complex and Multifaceted Disorder, Z. Pelikan, Ed., 2011.

[14] S. Bonini, S. Bonini, A. Lambiase et al., "Vernal keratoconjunctivitis revisited: a case series of 195 patients with long-term followup," Ophthalmology, vol. 107, no. 6, pp. 1157-1163, 2000.

[15] D. P. Metz, A. S. Bacon, S. Holgate, and S. L. Lightman, "Phenotypic characterization of T cells infiltrating the conjunctiva in chronic allergic eye disease," Journal of Allergy and Clinical Immunology, vol. 98, no. 3, pp. 686-696, 1996.

[16] T. Kawayama, K. Matsunaga, Y. Kaku et al., "Decreased CTLA4+ and Foxp3+ CD25highCD4+ cells in induced sputum from patients with mild atopic asthma," Allergology International, vol. 62, no. 2, pp. 203-213, 2013.

[17] S. Genc, H. Eroglu, U. C. Kucuksezer et al., "The decreased CD4+CD25+ FoxP3+ T cells in nonstimulated allergic rhinitis patients sensitized to house dust mites," Journal of Asthma, vol. 49, no. 6, pp. 569-574, 2012.

[18] G. Xu, Z. Mou, H. Jiang et al., "A possible role of CD4+CD25+ T cells as well as transcription factor Foxp3 in the dysregulation of allergic rhinitis," Laryngoscope, vol. 117, no. 5, pp. 876-880, 2007.

[19] A. J. Reefer, S. M. Satinover, M. D. Solga et al., "Analysis of CD25hiCD4+ "regulatory" T-cell subtypes in atopic dermatitis reveals a novel TH2-like population," Journal of Allergy and Clinical Immunology, vol. 121, no. 2, pp. 415.e3-422.e3, 2008.

[20] A. Doganci, T. Eigenbrod, N. Krug et al., "The IL-6R $\alpha$ chain controls lung CD4+CD25+ Treg development and function during allergic airway inflammation in vivo," Journal of Clinical Investigation, vol. 115, no. 2, pp. 313-325, 2005.

[21] C. T. Luo and M. O. Li, "Transcriptional control of regulatory T cell development and function," Trends in Immunology, vol. 34, no. 11, pp. 531-539, 2013.
[22] J. M. Dwyer and C. Johnson, "The use of concanavalin A to study the immunoregulation of human T cells," Clinical and Experimental Immunology, vol. 46, no. 2, pp. 237-249, 1981.

[23] I. J. Goldstein and C. E. Hayes, "The lectins: carbohydratebinding proteins of plants and animals," Advances in Carbohydrate Chemistry and Biochemistry, vol. 35, pp. 127-340, 1978.

[24] D. Valmori, A. Merlo, N. E. Souleimanian, C. S. Hesdorffer, and M. Ayyoub, "A peripheral circulating compartment of natural naive CD4+ Tregs," Journal of Clinical Investigation, vol. 115, no. 7, pp. 1953-1962, 2005.

[25] M. C. Jiménez-Martínez, R. Lascurain, A. Méndez-Reguera et al., "O-Glycosylation of NnTreg lymphocytes recognized by the Amaranthus leucocarpus lectin," Clinical and Developmental Immunology, vol. 2013, Article ID 506807, 9 pages, 2013.

[26] J. W. Lowenthal, E. Bohnlein, D. W. Ballard, and W. C. Greene, "Regulation of interleukin 2 receptor $\alpha$ subunit (Tac or CD25 antigen) gene expression: binding of inducible nuclear proteins to discrete promoter sequences correlates with transcriptional activation," Proceedings of the National Academy of Sciences of the United States of America, vol. 85, no. 12, pp. 4468-4472, 1988.

[27] C. Walker, J.-C. Virchow Jr., P. L. B. Bruijnzeel, and K. Blaser, "T cell subsets and their soluble products regulate eosinophilia in allergic and nonallergic asthma," Journal of Immunology, vol. 146, no. 6, pp. 1829-1835, 1991.

[28] S. R. Durham, S. J. Till, and C. J. Corrigan, "T lymphocytes in asthma: bronchial versus peripheral responses," Journal of Allergy and Clinical Immunology, vol. 106, supplement 5, pp. S221-S226, 2000.

[29] S. Werfel, W. Massey, L. M. Lichtenstein, and B. S. Bochner, "Preferential recruitment of activated, memory T lymphocytes into skin chamber fluids during human cutaneous late-phase allergic reactions," Journal of Allergy and Clinical Immunology, vol. 96, no. 1, pp. 57-65, 1995.

[30] P. Vijayanand, K. Durkin, G. Hartmann et al., "Chemokine receptor 4 plays a key role in $\mathrm{T}$ cell recruitment into the airways of asthmatic patients," Journal of Immunology, vol. 184, no. 8, pp. 4568-4574, 2010.

[31] G. Banfield, H. Watanabe, G. Scadding et al., "CC Chemokine Receptor 4 (CCR4) in human allergen-induced late nasal responses," Allergy, vol. 65, no. 9, pp. 1126-1133, 2010.

[32] B. Johansson-Lindbom and W. W. Agace, "Generation of guthoming $\mathrm{T}$ cells and their localization to the small intestinal mucosa," Immunological Reviews, vol. 215, no. 1, pp. 226-242, 2007.

[33] R. Elgueta, F. E. Sepulveda, F. Vilches et al., "Imprinting of CCR9 on CD4 T cells requires IL-4 signaling on mesenteric lymph node dendritic cells," Journal of Immunology, vol. 180, no. 10, pp. 6501-6507, 2008.

[34] N. Cerf-Bensussan, A. Jarry, N. Brousse, B. LisowskaGrospierre, D. Guy-Grand, and C. Griscelli, "A monoclonal antibody (HML-1) defining a novel membrane molecule present on human intestinal lymphocytes," European Journal of Immunology, vol. 17, no. 9, pp. 1279-1285, 1987.

[35] J. A. P. Gomes, H. S. Dua, L. V. Rizzo, M. Nishi, A. Joseph, and L. A. Donoso, "Ocular surface epithelium induces expression of human mucosal lymphocyte antigen (HML-1) on peripheral blood lymphocytes," British Journal of Ophthalmology, vol. 88, no. 2, pp. 280-285, 2004.

[36] K. L. Cepek, S. K. Shaw, C. M. Parker et al., "Adhesion between epithelial cells and T lymphocytes mediated by E-cadherin and the $\alpha($ E) $\beta 7$ integrin," Nature, vol. 372, no. 6502, pp. 190-193, 1994. 
[37] J. Lehmann, J. Huehn, M. de la Rosa et al., "Expression of the integrin $\alpha \mathrm{E} \beta 7$ identifies unique subsets of $\mathrm{CD} 25+$ as well as CD25- regulatory T cells," Proceedings of the National Academy of Sciences of the United States of America, vol. 99, no. 20, pp. 13031-13036, 2002.

[38] K. Suzuki, T. Okuno, M. Yamamoto et al., "Semaphorin 7A initiates T-cell-mediated inflammatory responses through $\alpha 1 \beta 1$ integrin," Nature, vol. 446, no. 7136, pp. 680-684, 2007.

[39] A. K. Czopik, M. S. Bynoe, N. Palm, C. S. Raine, and R. Medzhitov, "Semaphorin 7A is a negative regulator of T cell responses," Immunity, vol. 24, no. 5, pp. 591-600, 2006.

[40] M. C. Catley, J. Coote, M. Bari, and K. L. Tomlinson, "Monoclonal antibodies for the treatment of asthma," Pharmacology and Therapeutics, vol. 132, no. 3, pp. 333-351, 2011. 


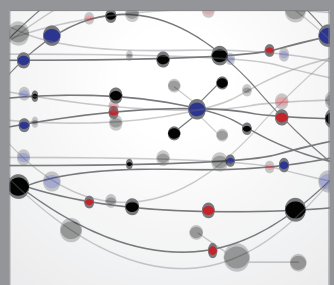

The Scientific World Journal
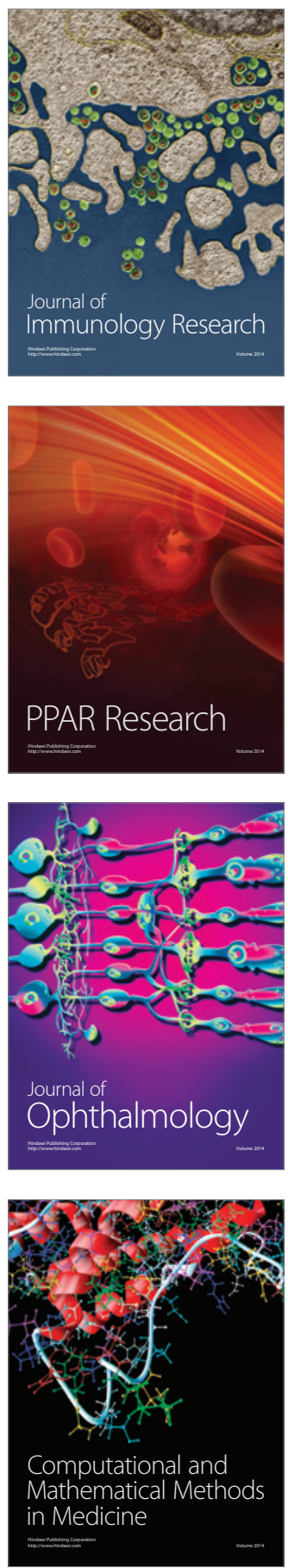

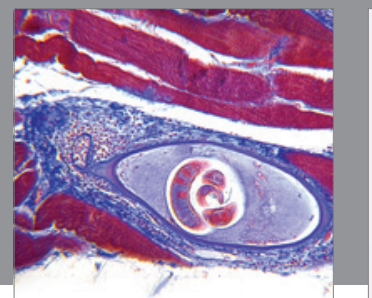

Gastroenterology

Research and Practice
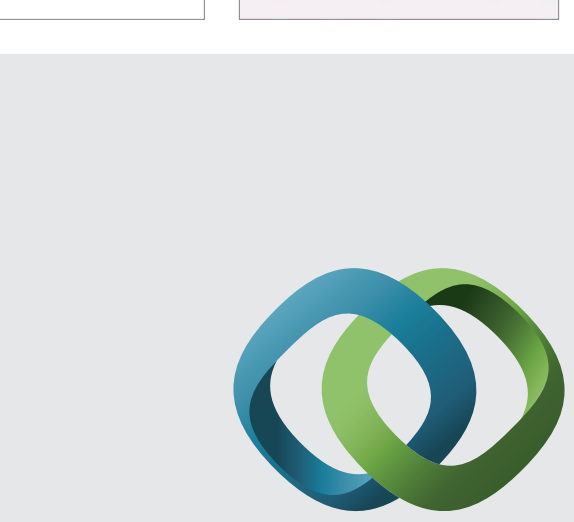

\section{Hindawi}

Submit your manuscripts at

http://www.hindawi.com
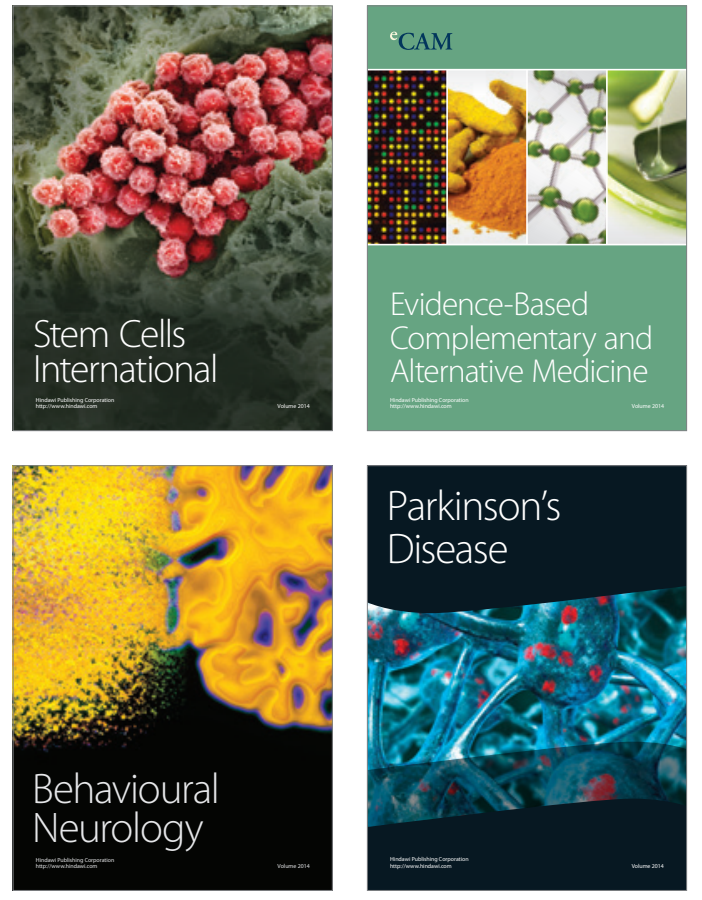
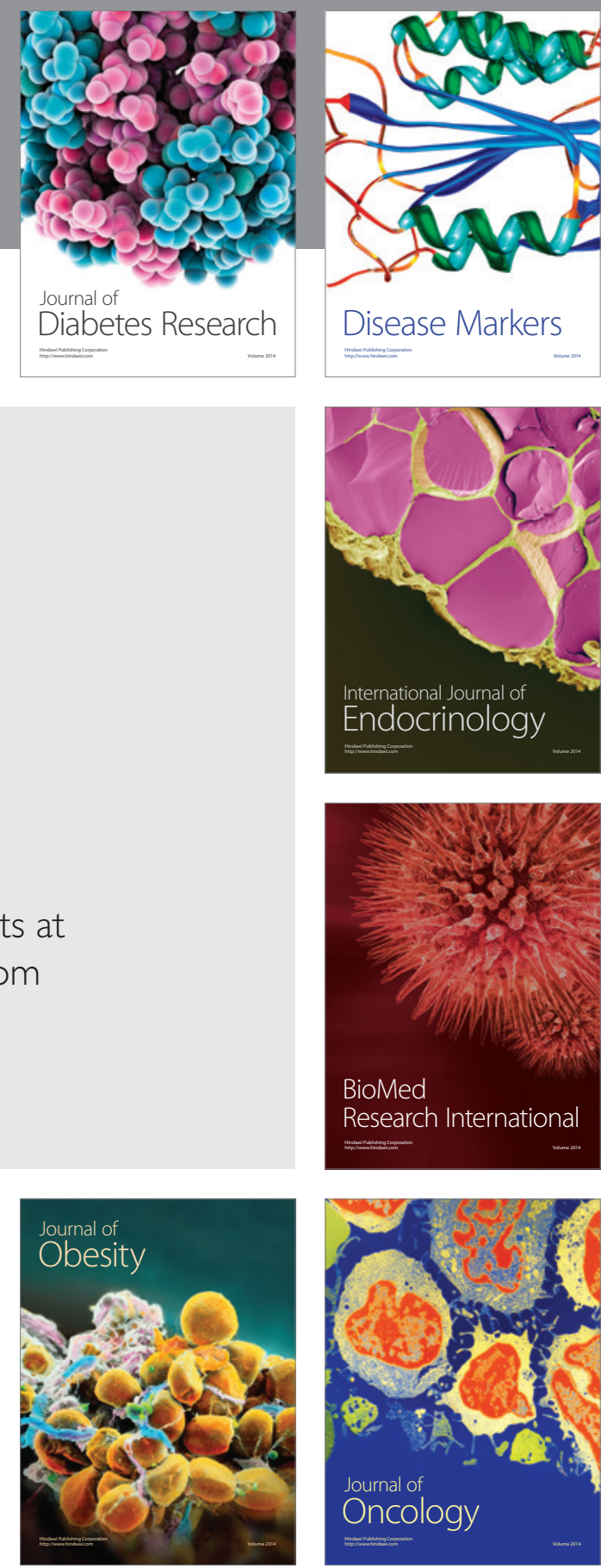

Disease Markers
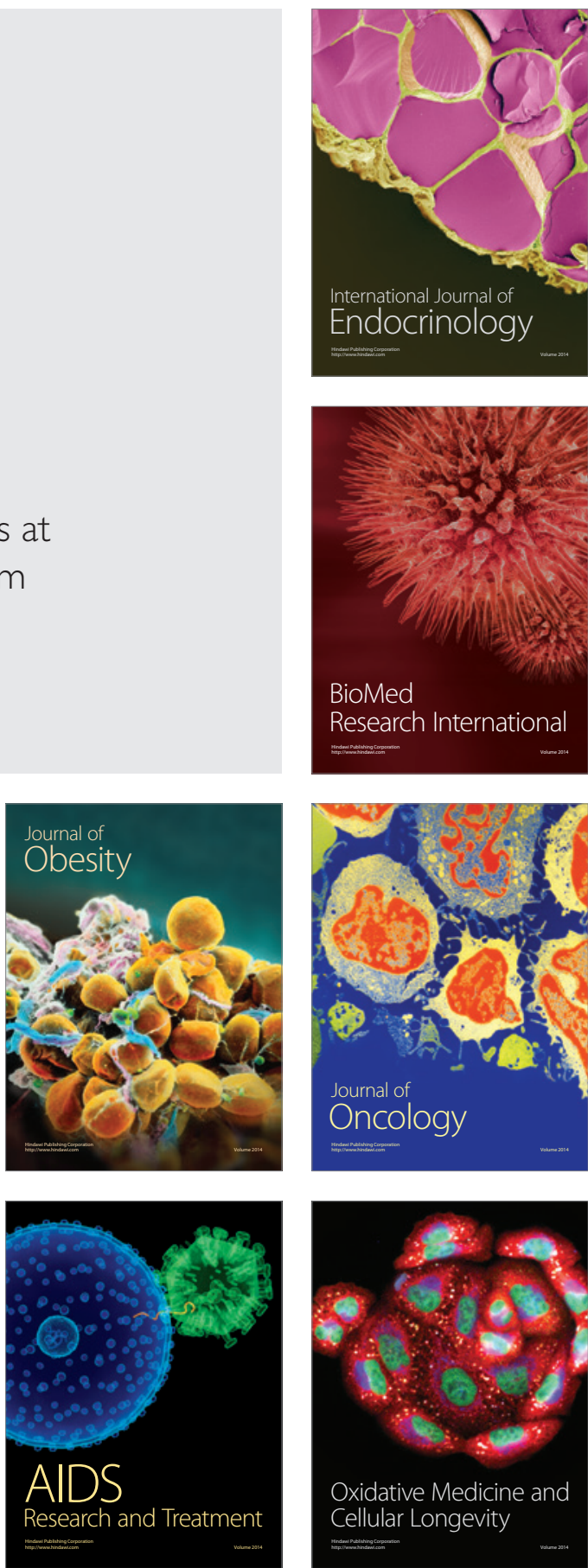